\title{
Skiftarbeid, søvn og helse blant sykepleiere
}

Roterende turnus påvirker søvnen mer negativt enn ikke-roterende turnus og nattarbeid.

\section{Forfattere}

\section{Eirunn Thun}

Psykolog og forsker

Universitetet i Bergen

\section{Ståle Pallesen}

Seniorforsker og professor

Universitetet i Bergen og Haukeland universitetssjukehus

\section{Siri Waage}

Senterkoordinator og postdoktor

Universitetet i Bergen og Haukeland universitetssjukehus

\section{Iselin Reknes}

Ph.d.-kandidat

Universitetet i Bergen

\section{Bente Elisabeth Moen}

Lege og professor

Senter for internasjonal helse, Institutt for global helse og samfunnsmedisin, Universitetet i Bergen

\section{Bjørn Bjorvatn}

Leder og professor

Nasjonal kompetansetjeneste for søvnsykdommer, Haukeland universitetssjukehus og Universitetet i Bergen

\section{Nøkkelord}

\section{Turnusarbeid Sykepleiere Søvn Psykososiale forhold}

Sykepleien 2017 105(7)(40-42)

DOI: https://doi.org/10.4220/Sykepleiens.2017.62099 
Spørreundersøkelsen om skiftarbeid, søvn og helse (SUSSH) har siden 2008/2009 årlig blitt sendt ut til om lag 2900 norske sykepleiere. Årets spørreskjema, som sendes ut i løpet av våren og sommeren 2017, er nummer ni i rekken. For å gjøre resultatene fra spørreundersøkelsen kjent for norske sykepleiere har vi med jevne mellomrom rapportert resultatene i Sykepleien (1-7).

I denne artikkelen gir vi en kortfattet oppsummering av artiklene som ble publisert $\mathrm{i}$ internasjonale tidsskrifter i løpet av 2016, totalt seks artikler (8-13). Disse artiklene omhandlet temaer som insomni og søvnighet, skiftarbeidstoleranse, mobbing på arbeidsplassen, personlighet og arbeidsnarkomani.

\section{Natt- og skiftarbeid}

I en av studiene publisert i 2016 undersøkte vi hvordan insomnisymptomer og søvnighet utviklet seg hos sykepleiere i en periode på fem til seks år (9). Sykepleiere som hadde nattarbeid i turnusen sin hele denne perioden, hadde ikke mer insomni eller søvnighet, eller en økning av slike symptomer over tid, sammenliknet med dem som ikke hadde nattarbeid. De som startet med nattarbeid i løpet av perioden, hadde heller ingen økning av symptomer i perioden. De som sluttet med nattarbeid i løpet av denne tiden, rapporterte derimot om en nedgang $\mathrm{i}$ insomni og søvnighet. 
Sykepleiere som hadde roterende turnus, rapporterte mer insomni og søvnighet, men opplevde ingen økning av disse symptomene over tid sammenliknet med sykepleiere som jobbet fast enten bare på dag eller på natt. De som startet med roterende turnus i løpet av perioden, hadde heller ingen økning i symptomer over tid, mens de som sluttet med en slik turnus, opplevde en nedgang i både insomni og søvnighet.

Roterende turnus ser dermed ut til å være forbundet med et stabilt høyere nivå av insomni og søvnighet enn ikke-roterende arbeidstidsordninger. Det at de som sluttet med nattarbeid eller roterende turnus, hadde en nedgang i symptomer, kan bety at de som opplever problemer i en type turnusordning, velger seg vekk fra denne.

\section{Genetikk}

Blant sykepleierne som svarte på det første spørreskjemaet i 2008/2009, inviterte vi i etterkant et utvalg som skulle avgi blodprøver for genanalyser. Vi analyserte prøver fra totalt 691 sykepleiere for å identifisere individuelle forskjeller i klokkegener, som er involvert i døgnrytmeregulering. Deretter koplet vi genprofilene opp mot informasjon om insomni, søvnighet og skiftarbeidslidelse fra spørreskjemaene.

Skiftarbeidslidelse refererer til insomni og/eller søvnighet som følge av å jobbe på et tidspunkt man normalt ville sovet. Resultatene fra denne studien viste at det ikke var noen klare sammenhenger mellom individuelle forskjeller i klokkegener og symptomer på insomni, søvnighet eller skiftarbeidslidelse (10).

\section{Angst og depresjon}


I en studie hvor vi undersøkte forløpere til og konsekvenser av insomni, fant vi at angst og depresjon var forbundet med en økning i insomnisymptomer over tid (8). Insomni predikerte på den annen side en økning $\mathrm{i}$ angst over tid, men ikke en økning i depresjon. Vi fant også at enkelte personlighetsfaktorer og arbeidsrelaterte faktorer var forbundet med en økning i insomni. Dette er nærmere beskrevet i avsnittene nedenfor. I studien konkluderte vi med at insomni ofte er en konsekvens av individuelle og arbeidsrelaterte faktorer heller enn en forløper til dem.

\section{三 «Angst og depresjon var forbundet med en økning i insomnisymptomer over tid.»}

\section{Psykososiale forhold}

Datamaterialet vårt har også gjort det mulig å se på

faktorer som ikke er direkte knyttet til turnusarbeid. Vi refererer noen av resultatene her som vi tror har interesse for sykepleiere.

Hos mange turnusarbeidere kan jobben virke inn på familielivet, eller motsatt. Det å erfare at jobben virker negativt inn på familielivet, eller at familielivet virker negativt inn på jobben, var forbundet med en økning i insomnisymptomer over tid. At jobben virker positivt inn på familielivet, var i en av våre studier forbundet med en nedgang i insomnisymptomer over tid.

Familielivets positive innvirkning på jobben hadde ikke noen påvirkning på symptomutviklingen (8).

\section{Mobbing på jobben}


Vi fant også at det å være utsatt for mobbing på arbeidsplassen, predikerte en økning i insomnisymptomer over tid (8). I tillegg til å være en forløper for insomni kan slike opplevelser også være en forløper for angst. I en studie fra 2016 undersøkte vi hvordan individuell mestringsstil virker inn på sammenhengen mellom mobbing på arbeidsplassen og angst (11). Vi fant at sykepleiere som ble mobbet på arbeidsplassen, i mindre grad brukte en aktiv løsningsorientert mestringsstil enn sykepleiere som ikke ble mobbet.

\section{三 «Det å være utsatt for mobbing på arbeidsplassen, predikerte en økning $i$ insomnisymptomer over tid.»}

En aktiv løsningsorientert mestringsstil viste seg imidlertid å være hensiktsmessig kun ved mindre alvorlige tilfeller av mobbing. Ved mer alvorlige tilfeller av mobbing økte en aktiv mestringsstil sannsynligheten for angst, kanskje fordi de aktive forsøkene på å håndtere situasjonen ikke fører fram. Det vil ofte ikke være tilstrekkelig å bruke aktive mestringsstrategier til å beskytte seg mot angst forårsaket av mobbing på arbeidsplassen. Det vil sannsynligvis være helt nødvendig med organisatoriske tiltak for å hjelpe.

I en annen studie fant vi at rollekonflikt på arbeidsplassen, for eksempel det å måtte gjøre ting som man mener burde vært gjort annerledes, var forbundet med høyere skårer på søvnighet, utmattelse, angst og depresjon. Vi fant også at rettferdig lederskap var forbundet med lavere skårer på angst og depresjon. Sosial støtte var forbundet med lavere skårer på utmattelse, angst og depresjon (12).

\section{Skiftarbeidstoleranse}


Når det kommer til personlighet, undersøkte vi hvorvidt de tre komponentene av personlighetsfaktoren «robusthet», på engelsk «hardiness», kunne predikere ulike mål på skiftarbeidstoleranse ett eller to år senere hos nattarbeidende sykepleiere. De tre komponentene er følgende:

- utfordring (evne til å håndtere nye utfordringer),

- forpliktelse (virkelig gå inn for det man driver med), og

- kontroll (opplevelse av kontroll over ens situasjon).

Vi fant at utfordring predikerte nedgang i angst ett år etterpå, men ikke nedgang i depresjon eller utmattelse. Forpliktelse predikerte nedgang i utmattelse ett år etterpå, og nedgang i angst og depresjon to år etterpå. Kontroll predikerte verken angst, depresjon eller utmattelse. Det kan dermed se ut som at evnen til virkelig å gå inn for det man driver med, er viktig for motstandsdyktighet mot psykiske helseplager. Ingen av robusthetskomponentene predikerte søvnighet (12).

Når det gjelder personlighet og insomni, fant vi at personlighetstrekket «languidity», vansker med å overkomme tretthet, var forbundet med en økning i insomnisymptomer over tid, mens det å være morgenmenneske, A-menneske, var forbundet med en nedgang i insomnisymptomer over tid (8).

\section{Arbeidsnarkomani}

Vi undersøkte også om personlighetsfaktorer hadde sammenheng med endring i arbeidsnarkomani over en periode på to år (13). Arbeidsnarkomani innebærer en kombinasjon av overinvolvering i arbeid, lange arbeidsdager, høyere enn forventet arbeidsinnsats og en ukontrollerbar trang til å jobbe. Disse symptomene ble sett hos fire prosent av sykepleierne i studien. Personlighetsfaktorene som ble undersøkt, var følgende:

- ekstroversjon (grad av utadvendthet), 
- nevrotisisme (i hvilken grad man er emosjonelt ustabil),

- planmessighet (i hvilken grad man er organisert og punktlig),

- medmenneskelighet (i hvilken grad man er sympatisk og empatisk), og

- intellekt eller forestillingsevne (i hvilken grad man er intellektuelt orientert, har forestillingsevne og er åpen for erfaring).

\section{三 «Resultatene viste at kun nevrotisisme hadde sammenheng med økning i arbeidsnarkomani.»}

Samlet sett var skårene på arbeidsnarkomaniskalaen ganske stabile over de to årene, men med en liten økning. Resultatene viste at kun nevrotisisme hadde sammenheng med økning i arbeidsnarkomani. Da vi brukte en terskelverdi for å kategorisere sykepleiere etter hvorvidt de hadde eller ikke hadde arbeidsnarkomani, fant vi at de som ikke hadde arbeidsnarkomani verken ved første måling i 2012 eller andre måling i 2014, skåret lavere på nevrotisisme sammenliknet med andre sykepleiere. De som hadde arbeidsnarkomani ved begge målingene, skåret høyere på intellekt eller forestillingsevne sammenliknet med sykepleierne som ikke hadde arbeidsnarkomani på noen av målingene.

\section{Veien videre}


Samtidig med at vi sender ut årets spørreskjema (2017), vil vi rekruttere interesserte sykepleiere til et delprosjekt hvor vi skal undersøke immunparametre og kople denne informasjonen opp mot spørreskjemaet. Blodprøver som skal analyseres for cytokiner, tas av sykepleierne selv ved hjelp av «bloodspot»-metoden og sendes til oss i posten. «Bloodspot»-metoden innebærer at sykepleierne selv stikker seg i fingeren med en stikkepenn og setter bloddråper på blodprøvepapir. Deltakelse kompenseres med et gavekort.

I 2018 sender vi ut det tiende spørreskjemaet i SUSSH. Vi vil fortsette å skrive artikler om dataene som er samlet inn i årene som kommer, og rapportere resultatene i Sykepleien.

Takk til sykepleierne som deltar i SUSSH. Takk også til Norsk Sykepleierforbund for støtte og økonomisk bidrag.

\section{Referanser}

1. Flo E, Magerøy N, Moen BE, Pallesen S, Bjorvatn B. Nattarbeid gir helseproblemer. Sykepleien 2011;13:70-2. Tilgjengelig fra: https://sykepleien.no/f orskning/2011/11/nattarbeid-gir-helseproblemer (nedlastet 18.05.2017).

2. Thun E, Bjorvatn B, Moen BE, Magerøy N, Flo E, Pallesen S. Robuste og aktive sykepleiere tåler skiftarbeid. Sykepleien 2013;2:44-6. Tilgjengelig fra: https://sykepleien.no/forskning/2013/01/robuste-og-akt ive-sykepleiere-taler-skiftarbeid (nedlastet 18.05.2017).

3. Flo E, Magerøy N, Moen BE, Pallesen S, Bjorvatn B. Skiftarbeid gir søvnproblemer. Sykepleien 2013;3:68-9. Tilgjengelig fra: https://sykepleien.no/for skning/2013/02/skiftarbeid-gir-sovnproblemer (nedlastet 18.05.2017). 
4. Reknes I, Bjorvatn B, Einarsen S, Pallesen S, Magerøy N, Thun E, Moen E. Nye funn om turnusarbeid. Sykepleien 2014;7:36-9. Tilgjengelig fra: https://sykepleien.no/forskning/2014/06/nye-funnom-turnusarbeid (nedlastet 18.05.2017).

5. Lien TF, Pallesen S, Bjorvatn B, Moen BE. Skiftarbeid og sykefravær blant sykepleiere.

Sykepleien Forskning 2014;9:350-6. Tilgjengelig fra: https://sykepleien.no/forskning/2014/12/skiftarbeid-og -sykefravaer-blant-sykepleiere (nedlastet 18.05.2017).

6. Waage S, Thun E, Reknes I, Moen BE, Magerøy N, Pallesen S, Bjorvatn B. For få timer mellom vaktene påvirker søvn og helse. Sykepleien 2015;10:58-60. Tilgjengelig fra: https://sykepleien.no/ forskning/2015/09/mer-forskning-pa-skiftarbeid-blantnorske-sykepleiere (nedlastet 18.05.2017).

7. Waage S, Thun E, Reknes I, Moen BE, Magerøy N, Pallesen S, Bjorvatn B. Nattarbeid påvirker ikke menstruasjonen. Sykepleien 2016;9:446. Tilgjengelig fra: https://sykepleien.no/forskning/201 6/09/ingen-sammenheng-mellom-nattarbeid-og-uregel $\underline{\text { messige-menstruasjoner-blant-norske (nedlastet }}$ 18.05.2017).

8. Vedaa Ø, Krossbakken E, Grimsrud ID, Bjorvatn B, Sivertsen B, Magerøy N, Einarsen S, Pallesen S. Prospective study of predictors and consequences of insomnia: personality, lifestyle, mental health and work-related stressors. Sleep Medicine 2016;20:51-8.

9. Thun E, Bjorvatn B, Åkerstedt T, Moen BE, Waage S, Molde H, Pallesen S. Trajectories of sleepiness and insomnia symptoms in Norwegian nurses with and without night work and rotational work. Chronobiology International 2016;33:480-9. 
10. Thun E, Le Hellard S, Osland T, Bjorvatn B, Moen BE, Magerøy N, Steen V, Giddaluru S, Brattbakk H-R, Pallesen S. Circadian clock gene variants and insomnia, sleepiness, and shift work disorder. Sleep and Biological Rhythms 2016;14:5562.

11. Reknes I, Einarsen E, Pallesen S, Bjorvatn B, Moen BE, Magerøy N. Exposure to bullying behaviors at work and subsequent symptoms of anxiety: The moderating role of individual coping style. Industrial Health 2016;54:421-32.

12. Saksvik-Lehouillier I, Bjorvatn B, Magerøy N, Pallesen S. Hardiness, psychosocial factors and shift work tolerance among nurses. A two year follow-up study. Journal of Advanced Nursing 2016;72:1800-12.

13. Andreassen CS, Bjorvatn B, Moen BE, Waage S, Magerøy N, Pallesen S. A longitudinal study of the relationship between the five-factor model of personality and workaholism. TPM: Testing, Psychometrics, Methodology in Applied Psychology 2016;23:285-98. 